\title{
Effects of different plant hormones on callus induction and plant regeneration of miniature roses (Rosa hybrida L.)
}

\begin{abstract}
Miniature roses (Rosa hybrida L.) are increasingly popular flowering potted plants. In this study, we used leaves of new cultivars of Rosa hybrida as explants and MS medium as basal medium, to explore optimal combinations and concentrations of growth regulators on callus, adventitious buds and root induction. Our results demonstrated that MS medium supplemented with $3.0 \mathrm{mgL}^{-1}$ 2,4-dichlorophenoxyacetic acid $(2,4-\mathrm{D})$ and $1.0 \mathrm{mgL}^{-1}$ 6-Benzylaminopurine (6-BA) could result to $100 \%$ callus induction ratio. Furthermore, we showed that 6-BA was of essential importance during the induction of adventitious buds in R.hybrida. On MS medium containing $1.0 \mathrm{mgL}^{-1} 6-\mathrm{BA},(0.05-0.5) \mathrm{mgL}^{-1}$ naphthaleneacetic acid (NAA) and (0.02-0.2) $\mathrm{mgL}^{-1}$ Thidizuron (TDZ), adventitious buds could be regenerated from calli and the redifferentiation ratio reached $92.6 \%$. Of note, our data supported the indispensable role of auxin during rooting induction, because 1/4MS medium enabled $100 \%$ rooting frequency when $0.1 \mathrm{mgL}^{-1}$ NAA was supplemented. In conclusion, we have established a tissue culture system, by which superior frequency of tissue regeneration and biologically similar cultures of R.hybrida could be achieved.
\end{abstract}

Volume 2 Issue 4 - 2018

\author{
Jiayu Liu, Huan Feng, Yanqin Ma, Li Zhang, \\ Haitao Han, Xuan Huang \\ Department of Life Science, Northwest University, China
}

Correspondence: Xuan Huang, Provincial Key Laboratory of Biotechnology of Shaanxi, Key Laboratory of Resource Biology and Biotechnology in Western China, Ministry of Education, College of Life Science, Northwest University, Xi'an 710069, China, Tell: +86-29-8830-3484, Fax: +86-29-8830-3572, Email xuanhuang@nwu.edu.cn

Received: September 27, 2017| Published: August 23, 2018

\section{Introduction}

Miniature roses (Rosa hybrida L.) are perennial evergreen or deciduous shrubs and a new variety of the rose family. A number of species, hybrids and cultivars of genus Rosa are widely used as garden plants, cut flowers, potted plants and for the perfume industry. ${ }^{1,2}$ In Europe, potted miniature roses are of great interest and their popularity is increasing in North America as well. ${ }^{3,4}$ In Denmark, approximately 35 million potted rose plants have been produced annually during the last 5 years. ${ }^{5}$ Moreover, due to the low maintenance requirement and extended flowering time, it has been proved to be attractive to consumers globally. Although extensive efforts have been made to enhance the quality and production of these plants since 1990s, but still a lot of improvement can be done. ${ }^{6,7}$ To date, studies on the factors controlling in vitro rooting have been limited to a few species. The frequency of establishment of rooted plants in field triasl was low and highly inconsistent. ${ }^{9-11}$ Callus induction is a powerful tool to regenerate plants. Callus is a disorganized mass of undifferentiated tissue comprised of actively dividing cells. The cells of callus dedifferentiate and thus regain their meristematic properties, including rapid proliferation. ${ }^{12}$

As for growth hormones, Cytokinins and auxins are the most commonly used for plant regeneration. Explants of Rosa species were commonly cultured on a full- or half-strength Murashige \& Skoog ${ }^{13}$ (MS) medium, supplemented with $0.05-5 \mathrm{mgL}^{-1}$ auxin $(2,4-$ D or NAA) usually in combination with a Cytokinins [BA, zeatin or kinetin (Kin)]. ${ }^{14}$ TDZ a substituted phenyl urea (N-phenyl-N-1,2,3thiadiazol-5-ylurea) is used as a synthetic herbicide and a plant growth regulator to stimulate high rate of auxiliary shoot proliferation in many woody plant species. ${ }^{15}$ The effect of TDZ has proven very efficient in regeneration of some species. ${ }^{16}$ But no reports on adventitious bud induction by TDZ treatment in this new varieties have been found. In this study, a new cultivar yellow color miniature rose was used as material to exam the effects from different cultivation practices, such as the duration and the presence of the apical bud. Several plant growth regulators, alone or in combination, and culture conditions were tested for their capacity to induce callus, adventitious buds and root formation. The effect of TDZ on miniature rose adventitious bud induction was also tested in this experiment. Our objective of this study was to investigate the optimal cultivating conditions for this miniature rose by means of callus induction and plant regeneration. Thus the breeding time can be greatly shortened and the established high frequency regeneration system will provide foundation for further genetic manipulation of other relatives to $R$. hybrida.

\section{Materials and methods}

\section{Plant material}

The shoots harvested from $R$. hybrida, grown in the greenhouse at $(24 \pm 2)^{\circ} \mathrm{C}$, under a 16 -h photoperiod and a light intensity of $250 \mu \mathrm{Es}$ ${ }^{1} \mathrm{~m}^{-2}$, were used as the explants. First, the explants were washed thoroughly by running water. The washed explants were then surface sterilized by submersing in $75 \%$ ethanol for 30 40 s, followed by washing with $0.1 \%$ mercuric chloride $\left(\mathrm{HgCl}_{2}\right)$ solution for $2 \sim 6 \mathrm{~min}$, and finally rinsed with sterile distilled water for $3 \sim 5$ times. Under sterile conditions, leaves, petioles, and stems from the explants were cut into small pieces $(0.5 \mathrm{~cm} \times 0.5 \mathrm{~cm}$, or a piece of $\mathrm{cm}$ long $)$, so fresh wounds were exposed and subjected into further application.

\section{Medium and culture conditions}

$\mathrm{MS}^{13}$-based medium ${ }^{13}$ (containing 3\% sucrose, $7.0 \mathrm{gL}^{-1}$ agar, $\mathrm{pH}$ 5.8-6.2) was used throughout the study. Callus and adventitious buds induction were performed using high-pressure sterilized MS medium supplemented with various concentrations of 6-benzylaminopurine (6-BA), naphthaleneacetic acid (NAA), 2,4-dichlorophenoxyacetic acid (2,4-D ) or Thidiazuron (TDZ). To the rooting were MS basal mediums, 1/2MS medium, and 1/4MS medium complemented with (0.05-0.5) $\mathrm{mgL}^{-1} \mathrm{NAA}$, or $1 / 4 \mathrm{MS}$ basal medium with no 
supplements. Explants were grown in a chamber at $(24 \pm 2)^{\circ} \mathrm{C}$, under a 16-h photoperiod and a light intensity of $40 \mu \mathrm{Es}^{-1} \mathrm{~m}^{-2}$.

\section{Callus induction}

The explants were cultivated on MS medium supplemented with different concentrations or combinations of growth hormones (Table1) in sterile Petri dishes (8-15 explants per Petri dish) for callus induction. The explants were transferred to fresh medium every 3 weeks until callus were observed. The optimal medium and the induction frequency were recorded, respectively.

Table I Effects of different plant growth regulators on callus induction of R.hybrida

Values represent the means $\pm S$.E. Means followed by the same different letters are not significantly different at $p<0.0$ I

\begin{tabular}{lllllll}
\hline Number & $\begin{array}{l}\text { Basic } \\
\text { medium }\end{array}$ & \multicolumn{2}{l}{$\begin{array}{l}\text { Phytohormone } \\
\text { proportion }\left(\mathbf{m g} \cdot \mathbf{L}^{-1}\right)\end{array}$} & $\begin{array}{l}\text { Number } \\
\text { of } \\
\text { explants }\end{array}$ & $\begin{array}{l}\text { Frequency } \\
\text { of Callus } \\
\text { induction } \\
(\%)\end{array}$ \\
\hline 1 & MS & 0.1 & 0.5 & 0 & 41 & $28.3 \pm 1.4^{\mathrm{e}}$ \\
2 & MS & 0.5 & 0.1 & 0 & 50 & $8.3 \pm 1.9^{\mathrm{f}}$ \\
3 & MS & 0.5 & 1 & 0 & 42 & $70 \pm 1.1^{\mathrm{c}}$ \\
4 & MS & 1 & 0.1 & 0 & 39 & $65 \pm 0.7^{\mathrm{cd}}$ \\
5 & MS & 1 & 0.3 & 0 & 44 & $73.3 \pm 0.9^{\mathrm{c}}$ \\
6 & MS & 1 & 0 & 2 & 48 & $80 \pm 1.4^{\mathrm{b}}$ \\
7 & MS & 1 & 0 & 3 & 60 & $100 \pm 0^{\mathrm{a}}$ \\
8 & MS & 1 & 0 & 4 & 58 & $96.7 \pm 0.5^{\mathrm{a}}$ \\
9 & MS & 1 & 0 & 5 & 55 & $91.7 \pm 2.3^{\mathrm{ab}}$ \\
10 & MS & 2 & 0 & 2 & 40 & $60.6 \pm 1.6^{\mathrm{d}}$ \\
\hline
\end{tabular}

\section{Shoot regeneration}

After 30 day multiplication, proliferated calli on callus induction medium with a diameter of $1.0-1.5 \mathrm{~cm}$ were dissected into smaller, fixed callus masses (about $0.7 \mathrm{~cm}^{3}$ per piece), and transferred to adventitious buds induction media (Table 2). The incubation conditions for shoot regeneration were identical for callus induction. Next, adventitious buds reached $2-3 \mathrm{~cm}$ in length were transferred to various rooting media mentioned above in Medium and culture conditions. When induced roots grew to about $2 \mathrm{~cm}$ in length, rooted shoots (plantlets) were cultured for an additional 2-4day after removing the Parafilm, i.e., in vitro acclimatization. Afterwards, plantlets were taken out of culture flasks (adhesive media and loose callus were rinsed off) and pre-transplanted into nutritive soil to culture for 3-5 days, and then transplanted into potting medium in flowerpots placed in the greenhouse.

\section{Statistical analysis}

All data analysis was performed with Origin version 8.0. Values were expressed as mean \pm S.E, and statistical analysis were performed by a one-way Anova. Significant differences between means were test by Duncan's t-test. Asterisks indicated significant difference $\left(\mathrm{P}<0.05^{*}\right.$, $\mathrm{P}<0.01^{* *}$,). Means followed by different letters are significantly different at $\mathrm{P}<0.05$. Entries with a same letter are not significantly different at $\mathrm{P}<0.05$. The percentage callus induction (induction $\%)=($ No. of explants producing callus/No. of explants inoculated $) \times$ $100 \%$. The percentage callus redifferentiation (Induction \%) $=($ No. of calli producing adventitious buds/No. of calli inoculated) $\times 100 \%$.

\section{Results}

\section{The influence of different growth periods of callus induction}

Based on our results, young leaves of R.hybrida were shown to be most effective in callus induction and whole plant regeneration, in comparison to petioles, stems as explants (no data shown). Young leaves harvested at 6-, 9-, 12-, 15- or 21-day old were used as explants for callus induction. The results indicated that 12-day old leaves had significantly higher survival percentage $(100 \pm 0 \%)$ as explants compared to the 21 -day old leaves $(9.8 \pm 1.2 \%)$. This suggests a clear correlation between the age of leaves and successful callus induction (Fig.1).

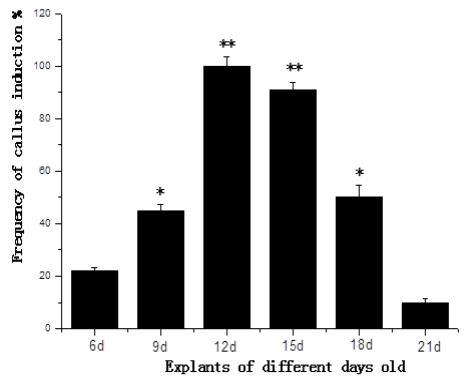

Figure I Influence of different growth periods of leaves on callus induction of R.hybrida. MS medium with $3.0 \mathrm{mgL}^{-1}$ 2,4-D and $1.0 \mathrm{mgL}^{-1} 6-\mathrm{BA}$.* $\mathrm{p}<0.05$, ** $\mathrm{p}<0.0$ I, significantly lower versus control, using Dunnett's test.

\section{Effects of different plant growth regulators on callus induction}

Phytohormones were used to induce somatic embryos usually containing 2,4-D, NAA ,6-BA. ${ }^{17}$ In this experiment, young leaves of R.hybrida were made as explants, and cultured on MS medium supplemented with different concentrations and combinations of auxin or cytokinin. As shown in Table 1, the optimal concentration of 6-BA for callus induction was $1.0 \mathrm{mgL}^{-1}$. A higher concentration of NAA $\left(1.0 \mathrm{mgL}^{-1}\right)$ can partially recover the induction rate supplemented with low 6-BA concentration $\left(0.5 \mathrm{mgL}^{-1}\right)$. Under these conditions, calli can be observed after 4 to 7 days induction. The calli consistently showed a loose structure with moisturized surface and callus occurred within 4-7d (Figure 2A). To further determine the effects from 2,4-D on callus induction, various concentrations (3.0, 4.0 or $\left.5.0 \mathrm{mgL}^{-1}\right)$ of 2,4-D were added into the MS medium containing $1.0 \mathrm{mgL}^{-1}$ 6-BA After an one-month subculture, $3.0 \mathrm{mgL}^{-1}$ of 2,4-D resulted to most callus formations than the others. $100 \%$ of induction rate can be achieved by using the MS medium containing $3.0 \mathrm{mgL}^{-1} 2,4-\mathrm{D}$ and $1.0 \mathrm{mgL}-1$ 6-BA. Some of calli showed whitish to yellowish in color. Meanwhile, the results showed that with the increase of 2,4-D concentration, callus once developed from the $12 \mathrm{~d}$ leaves turned brown and hard after 10 weeks(no data shown). The induced callus became desiccated or necrotic when subculture on the same medium as that used for callus induction. With the increase of subculture generation, callus differentiation capacity decreased and become browning at the same time. In addition, high concentration of 6-BA and NAA was not favorable for callus differentiation. Higher concentrations of NAA led to the formation of foamy, loose, and soft texture in calli, which was not conducive to the formation of 
adventitious buds. The calli were compact low water content?? And not conducive to further differentiation when concentration of 6-BA increased (data not shown).

\section{Effects of different plant growth regulators on callus dedifferentiation}

After callus induction, the well grown calli were transferred onto plant regeneration medium. We can see 6-BA and NAA play crucial roles in regulating acclimatization and helping survival of calli induced from explants (Table 2). With very low concentration of TDZ $\left(0.02 \mathrm{mgL}^{-1}\right)$ contributes a lot on plant regeneration ratio. The results indicated TDZ was suitable for callus growth and differentiation into green buds (Figure 2B). However, calli easily became hard and browning if cultured in this medium after long incubation time. Individual calli were cut and transferred to the adventitious buds formation medium, which contained MS supplemented with various concentrations of 6 - BA $\left(0.0,0.5,1.0\right.$ and $\left.1.5 \mathrm{mgL}^{-1}\right), \mathrm{NAA}(0.0,0.05$ $, 0.1,0.5$ and $\left.1.0 \mathrm{mgL}^{-1}\right)$ and $\mathrm{TDZ}\left(0.0,0.01,0.02,0.1\right.$ and $0.2 \mathrm{mgL}^{-1}$ ) to determine the optimal adventitious buds formation medium. As shown in Table 2, significantly higher callus dedifferentiation rate (92.6\%) and adventitious buds (Figure 2C) was observed after 4-6 weeks of incubation on MS medium contained $1.0 \mathrm{mg} \mathrm{L}^{-1} 6$-BA, 0.1 $\mathrm{mg} \mathrm{L^{-1 }} \mathrm{NAA}$ and $0.02 \mathrm{mgL}^{-1} \mathrm{TDZ}$. Adventitious buds became thick and strong (Figure 2D) and reached 2-3cm in length (Figure 2E) after transferring to fresh medium 3-4 weeks later.

\section{Effects of different plant growth regulators on root formation}

The plant growth regulator NAA was used to promote root formation. Various concentrations $\left(0.05-0.5 \mathrm{mgL}^{-1}\right)$ of NAA were added to the MS medium, 1/2-strength and 1/4-strength MS medium to identify the optimal medium for root formation. The effects of four concentrations of basal medium on root regeneration in vitro of this cultivar was illustrated, including MS with $0.05-0.5 \mathrm{mgL}^{-1} \mathrm{NAA}$, $1 / 2 \mathrm{MS}$ with $0.05-0.5 \mathrm{mgL}^{-1} \mathrm{NAA}, 1 / 4 \mathrm{MS}$ with $0.05-0,5 \mathrm{mgL}^{-1} \mathrm{NAA}$, and $1 / 4 \mathrm{MS}$ with no supplements. Based on our observation, incubation time should be controlled within a reasonable time period otherwise the buds gradually turned into dark color and died eventually (data not shown). Root regeneration was recorded at this time. Highest percentage rooting was obtained by cultivated on 1/4-strength MS medium supplemented with $0.01 \mathrm{mg} \mathrm{L}^{-1}$ NAA. After 15 days incubation on root regeneration medium, the regenerated roots were growing healthy and elongated (Fig. $2 \mathrm{~F}$ and $2 \mathrm{G}$ ). The potted plants possessed $100 \%$ survivorship in the tissue culture room and all those that survived grew vigorously in the greenhouse (Figure $2 \mathrm{H}$ ).

Table 2 Effects of different plant growth regulators on callus redifferentiation of R.hybrida

Valus represent the means \pm S.E. Means followed by the same different letters are not significantly different at $p<0.0 \mathrm{I}$.

\begin{tabular}{|c|c|c|c|c|c|c|}
\hline \multirow{2}{*}{ No. } & \multicolumn{3}{|c|}{$\begin{array}{l}\text { Concentrations } \\
\text { of plant growth } \\
\left.\text { regulator(mg } \mathbf{L}^{-1}\right)\end{array}$} & \multirow{2}{*}{$\begin{array}{l}\text { Number } \\
\text { of induced } \\
\text { callus }\end{array}$} & \multirow{2}{*}{$\begin{array}{l}\text { Frequency } \\
\text { of callus } \\
\text { redifferentiation } \\
(\%)\end{array}$} & \multirow{2}{*}{ Description of growing status } \\
\hline & 6-BA & NAA & TDZ & & & \\
\hline I & 0 & 0 & 0 & 34 & $0^{\text {h }}$ & $\begin{array}{l}\text { No adventitious buds could be induced; calli grew slowly and } \\
\text { became yellow }\end{array}$ \\
\hline 2 & 0 & 0.05 & 0 & 30 & $0^{\text {h }}$ & No adventitious buds could be induced; calli became browning \\
\hline 3 & 0 & 0 & 0.02 & 35 & $0^{\text {h }}$ & No adventitious buds could be induced; calli became brown \\
\hline 4 & 0.5 & 0 & 0 & 36 & $0^{\text {h }}$ & $\begin{array}{l}\text { No adventitious buds could be induced; Compact green calli } \\
\text { became compact with green color }\end{array}$ \\
\hline 5 & 0.5 & 0.5 & 0 & 39 & $43.3 \pm 2.3^{e}$ & Slender, yellow-green adventitious buds were obtained \\
\hline 6 & 0.5 & I & 0 & 47 & $52.2 \pm 2.1^{d}$ & Slender, yellow-green adventitious buds were obtained \\
\hline 7 & 0.5 & 0 & 0.02 & 35 & $0^{\text {h }}$ & No adventitious buds could be induced \\
\hline 8 & 0.5 & 0 & 0.1 & 40 & $6.7 \pm 1.8^{\mathrm{g}}$ & Few buds were obtained; abnormal shape \\
\hline 9 & 0.5 & 0 & 0.2 & 42 & $0^{\text {h }}$ & No adventitious buds could be induced; calli kept on growing \\
\hline 10 & $\mathrm{I}$ & 0 & 0 & 40 & $0^{\text {h }}$ & $\begin{array}{l}\text { No adventitious buds could be induced; mild vitrification } \\
\text { phenomenon }\end{array}$ \\
\hline II & $\mathrm{I}$ & 0.05 & 0 & 47 & $71.0 \pm 2.8^{c}$ & Green adventitious buds were obtained; normal shape \\
\hline 12 & 1 & 0.1 & 0 & 49 & $80.6 \pm 3.0^{b}$ & $\begin{array}{l}\text { Cluster buds can be induced; Buds were thick and strong; } \\
\text { growing fast; with green color }\end{array}$ \\
\hline 13 & $\mathrm{I}$ & 0.5 & 0 & 50 & $76.7 \pm 1.7^{\mathrm{bc}}$ & Cluster buds grew well and normal shape \\
\hline 14 & $\mathrm{I}$ & I & 0 & 47 & $74.4 \pm 2.5^{\mathrm{bc}}$ & Cluster buds can be induced; in yellow color and slender shape \\
\hline 15 & 1 & 0 & 0.02 & 32 & $3.4 \pm 2.1^{g}$ & Few adventitious buds were obtained; abnormal shape \\
\hline 16 & I & 0 & 0.1 & 39 & $0^{\text {h }}$ & No adventitious buds were obtained; calli kept on growing \\
\hline
\end{tabular}


Table continued

\begin{tabular}{|c|c|c|c|c|c|c|}
\hline \multirow[t]{2}{*}{ No. } & \multicolumn{3}{|c|}{$\begin{array}{l}\text { Concentrations } \\
\text { of plant growth } \\
\text { regulator }\left(m g \mathrm{~L}^{-1}\right)\end{array}$} & \multirow{2}{*}{$\begin{array}{l}\text { Number } \\
\text { of induced } \\
\text { callus }\end{array}$} & \multirow{2}{*}{$\begin{array}{l}\text { Frequency } \\
\text { of callus } \\
\text { redifferentiation } \\
\text { (\%) }\end{array}$} & \multirow[t]{2}{*}{ Description of growing status } \\
\hline & 6-BA & NAA & TDZ & & & \\
\hline 18 & I & 0.05 & 0.2 & 44 & $87.7 \pm 0.9^{\mathrm{a}}$ & $\begin{array}{l}\text { Cluster buds can be induced; Buds were thick and strong; } \\
\text { growing fast; in green color }\end{array}$ \\
\hline 19 & I & 0.1 & 0.02 & 45 & $92.6 \pm 3.4^{\mathrm{a}}$ & $\begin{array}{l}\text { Cluster buds can be induced; Buds were thick and strong; } \\
\text { growing fast; in green color; significantly high adventitious buds } \\
\text { induction rate was shown }\end{array}$ \\
\hline 20 & 1.5 & 0.05 & 0 & 46 & $40.1 \pm 2.1^{\mathrm{e}}$ & $\begin{array}{l}\text { Adventitious buds could be induced; buds were slender and } \\
\text { browning }\end{array}$ \\
\hline 21 & 1.5 & 0.5 & 0 & 49 & $32.2 \pm 3.7^{f}$ & $\begin{array}{l}\text { Adventitious buds could be induced; in yellow-green color; not } \\
\text { growing well }\end{array}$ \\
\hline 22 & 1.5 & 0 & 0.02 & 47 & $0^{\text {h }}$ & $\begin{array}{l}\text { No adventitious buds could be induced; calli became hard and } \\
\text { browning }\end{array}$ \\
\hline 23 & 1.5 & 0 & 0.2 & 42 & $0^{\mathrm{h}}$ & $\begin{array}{l}\text { No adventitious buds could be induced; calli became hard } \\
\text { browning }\end{array}$ \\
\hline
\end{tabular}
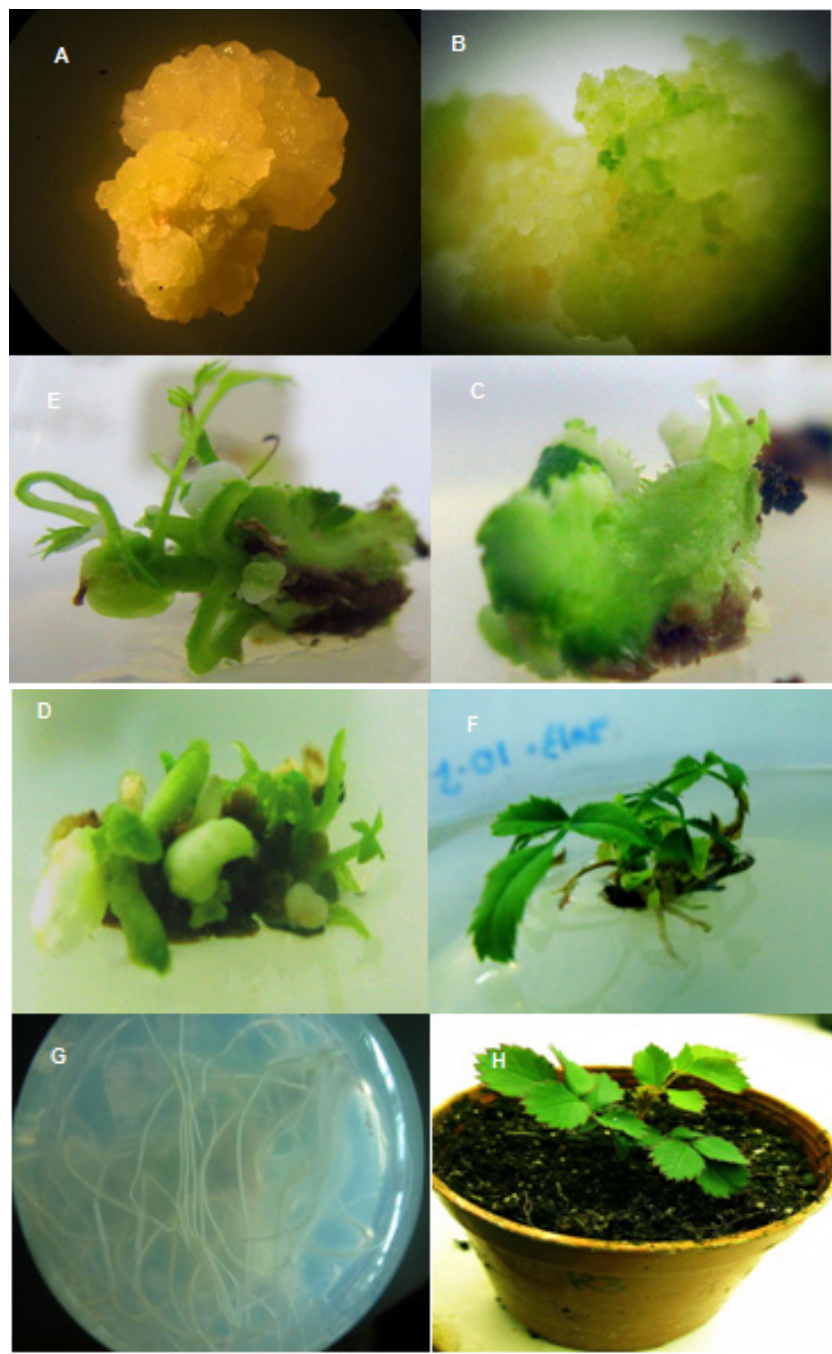

Figure 2 Callus induction and plantlet regeneration of R. hybrida.A: Calli were induced from leaves; B: Multiple green buds could be observed from calli growing on MS medium containing $3.0 \mathrm{mgL}-\mathrm{I}$ 2,4-D, I.0 mgL-I 6-BA; C\&D:Adventitious buds could be regenerated from calli on MS medium added I.0 mgL-I 6-BA, 0.I mg L-I NAA and 0.02 mgL-I TDZ; E: Healthy buds; F\&G: Root regenerated from adventitious buds after I5-day-caltivation on I/4MS medium supplemented with $0.1 \mathrm{mgL}-\mathrm{I} \mathrm{NAA} ; \mathrm{H}$ :Ten days after transferring a regenerated seedling into pot. 


\section{Discussion and conclusion}

\section{Effect of different concentrations of plant growth regulators on callus induction}

The ages and kinds of explants showed significant impacts on callus regeneration. The highest callus induction rate was obtained by using 12-day old young leaves as explants. Young leaves are ideal explants because they are healthy, non-senescing, nutrient-rich tissues and containing higher concentrations of endogenous hormones. ${ }^{18}$ Other studies have also shown success in callus induction and plant regeneration by using young leaves. For example, ${ }^{19}$ used shoot (including young leaves) to examine the effects of liquid culture system on the growth and development of miniature rose (Rosa chinensis Jacq. 'Minima') and the best culture medium was achieved. Likewise, Tian \& $\mathrm{He}^{20}$ established a high frequency regeneration system of kiwi fruit by using leaf explants of Actinidia deliciosa Qinmei. To date, 2,4-D, 6-BA, NAA are the most common growth phytohormones used for plant regeneration. In our study, different combinations of 2, 4-D and 6-BA or NAA were tested, which have resulted to distinct callus percentages (Table 1). In combination with 6-BA, 2, 4-D showed indispensable effects for callus induction 2, 4-D increased the number of explants which lead the bud to form, but was not essential for morphogenesis. ${ }^{21}$ However, the induced callus became desiccated or necrotic when subculture on the same medium as that used for callus induction. Importantly, the addition of 6-BA in the medium apparently provides new opportunities for further development of the regenerated plants. Furthermore, the use of different concentrations of plant growth regulators showed a significant impact on the callus induction. Our results indicated that high concentrations of 2,4-D can cause callus browning in the subsequent training process, which will adversely affect the regeneration process. For example, when the medium was added with 2,4-D ranging from $3.0 \mathrm{mgL}^{-1}$ to $5.0 \mathrm{mgL}^{-1}$, the results showed a high degree of browning callus. In particular, when the 2,4-D concentration was $5.0 \mathrm{mgL}^{-1}$, abnormal embryos would appear, and it was not able to develop into shoots, seriously affecting the plant regeneration frequency. This could be explained by the mutations caused by 2,4-D in the cells, thus affecting the regeneration frequency differentiation. ${ }^{22,23}$ In addition, 2,4-D can induce or inhibit somatic embryogenesis at the same time. ${ }^{24}$

Therefore, in order to reduce the inhibitory effect of high concentrations of 2,4-D, it is wise not to use high concentrations of 2,4-D in callus induction process of R.hybrida. For most plants, the use of auxin alone failed to induce somatic embryos. As a result, using an appropriate combination ratio of auxin and Cytokinins is a key factor for somatic embryogenesis. ${ }^{25,26}$ MS basal medium containing $1.0 \mathrm{mgL}^{-1}$ 6-BA and $3.0 \mathrm{mgL}^{-1}$ 2,4-D has been the most efficient medium to display callus induction in R.hybrida.

Table 3 Effects of different plant growth regulators on adventitious buds induction of $R$. hybrida

"+" as can be regenerated , the number of "+" indicates the degree of the depth. "." on the contrary

\begin{tabular}{llllll}
\hline Treatment & $\begin{array}{l}\text { Basic } \\
\text { medium }\end{array}$ & $\begin{array}{l}\mathbf{6 - B A} \\
\left(\mathbf{m g} \cdot \mathbf{L}^{-1}\right)\end{array}$ & $\begin{array}{l}\mathbf{N A A} \\
\left(\mathbf{m g} \cdot \mathbf{L}^{-1}\right)\end{array}$ & $\begin{array}{l}\mathbf{T D Z} \\
\left(\mathbf{m g} \cdot \mathbf{L}^{-1}\right)\end{array}$ & $\begin{array}{l}\text { Effect } \\
\text { degree }\end{array}$ \\
\hline 1 & MS & 1 & 0.05 & 0 & + \\
2 & MS & 1 & 0.1 & 0 & ++ \\
3 & MS & 1 & 0.2 & 0 & +++ \\
\hline
\end{tabular}

\begin{tabular}{llllll}
\hline Treatment & $\begin{array}{l}\text { Basic } \\
\text { medium }\end{array}$ & $\begin{array}{l}\mathbf{6 - B A} \\
\left(\mathbf{m g} \cdot \mathbf{L}^{-1}\right)\end{array}$ & $\begin{array}{l}\mathbf{N A A} \\
\left(\mathbf{m g} \cdot \mathbf{L}^{-1}\right)\end{array}$ & $\begin{array}{l}\mathbf{T D Z} \\
\left(\mathbf{m g} \cdot \mathbf{L}^{-1}\right)\end{array}$ & $\begin{array}{l}\text { Effect } \\
\text { degree }\end{array}$ \\
\hline 4 & MS & 1 & 0.3 & 0 & ++ \\
5 & MS & 1 & 1 & 0 & + \\
6 & MS & 2 & 0.5 & 0 & + \\
7 & MS & 3 & 0.1 & 0 & + \\
8 & MS & 0 & 1 & 0.02 & - \\
9 & MS & 0 & 1.5 & 0.02 & - \\
10 & MS & 0 & 2 & 0.01 & - \\
11 & MS & 1 & 0.05 & 0.2 & +++ \\
12 & MS & 1 & 0.2 & 0.02 & ++++ \\
13 & MS & 1 & 0.1 & 0.2 & ++ \\
\hline
\end{tabular}

\section{Callus redifferentiation}

Previous studies have shown 6-BA (as a Cytokinins) at certain concentration can promote callus subculture, differentiation and regeneration in most of plants. ${ }^{27} \mathrm{~A}$ combination with $1.0 \mathrm{mgL}^{-1}$ 6-BA and $0.1 \mathrm{mgL}^{-1}$ NAA showed great benefits for plant regeneration. In addition, we found that $0.02 \mathrm{mgL}^{-1}$ of TDZ significantly improved adventitious buds induction under light condition with 6-BA and 2, 4-D. TDZ is a phenyl urea derivative with strong cytokinin activity, which plays an important role in $\mathrm{n}$ plants budding and somatic embryogenesis, and it has been considered to be more potent than most of the commonly used Cytokinins. ${ }^{28}$ Therefore, TDZ may have specific effects on enhancing plant regeneration. ${ }^{29}$ For example, According to Sanikhani et al., ${ }^{30}$ in all cultivars shoot regeneration frequency and a number of shoots per explants were enhanced by increasing TDZ concentration. However, Wang et al.,${ }^{31}$ found that the embryogenic callus formed mucus on the medium containing TDZ and no plant regeneration was observed, indicating TDZ was not suitable for inducing somatic embryogenesis and plant regeneration of S.robustus. The main reason was that TDZ may have different effects on somatic embryos of different plants species or different plants types. ${ }^{32}$ In addition, In woody plant species, low levels of TDZ induce the maxillary shoot proliferation but higher levels may inhibit it. Higher levels, on the other hand, promote callus and somatic embryo formation..$^{28}$

Thus, we added a small amount of concentration of TDZ to the 6-BA and NAA medium in this experiment. The results indicated that addition of TDZ promoted the formation of callus and greatly improved adventitious bud induction rate. TDZ content in the medium had significant influence on the regeneration efficiency, and led to efficient regeneration in all cultivars. ${ }^{33}$ Our method could be applied for both fast propagation of new cultivars and transformation in subsequent projects, which also demonstrates both the reproducibility of the procedure and the consistency of its results. In conclusion, a protocol for the regeneration from callus tissue has been successfully established. The best plantlet regeneration and multiplication occurred on the following media:

1. $100 \%$ callus induction on MS medium containing $3.0 \mathrm{mgL}^{-1} 2,4$ $\mathrm{D}, 1.0 \mathrm{mgL}^{-1} 6-\mathrm{BA}$.

2. $92.6 \%$ shoot induction on MS medium supplemented with $1.0 \mathrm{mgL}^{-1}$ 6-BA, (0.05-0.5) $\mathrm{mgL}^{-1} \mathrm{NAA}$ and (0.02-0.2) $\mathrm{mgL}^{-1} \mathrm{TDZ}$.

3. $100 \%$ rooting on $1 / 4 \mathrm{MS}$ medium containing $0.1 \mathrm{mgL}^{-1} \mathrm{NAA}$. 
The tissue culture condition we developed here showed great efficiency and rapid propagation of this new cutivars of $R$. hybrida and may serve as a critical method for further laboratorial or commercial application.

\section{Acknowledgements}

None.

\section{Conflict of interest}

Author declares that there is no conflict of interest.

\section{References}

1. Short KC, Roberts AV. Rosa spp. (roses): In vitro culture, micropropagation and the production of secondary products. In: Bajaj YPS, editor. Biotechnology in agriculture and forestry. Medicinal and aromatic plants III. Berlin: Springer;1991;15;376-397.

2. Horn WAH. Micropropagation of Rose (Rosa L.). In: High Tech and micropropagation $I V$. Bajaj YPS, editor. Berlin: Springer;1992;20:320-342.

3. Borch K, Williams MH, Hoyer L. Influence of simulated transport on postharvest longevity of three cultivars of miniature potted rose. Acta Hortic. 1995;424:175-180.

4. Muller R, Andersen AS, Serek M, et al. Physiological and genetic reasons for different postharvest characteristics in miniature potted roses. Acta Hortic. 2001;543:153-157.

5. Floradania Marketing 2011:Top-14 Lists: Overview of the largest cultures produced Denmark 2005-2010.

6. Andersen AS, Serek M, Johansen P. Postproduction performance of potted rose cultivars. Nordiske Jordbrugsforskeres Forening Rpt. 1992;78:18-21.

7. Serek M, Andersen AS. Ethylene relations in the post harvest quality of potted rose. Intl Symp Physiology Ethylene Effects Moscow: Russian Academy of Sciences; 1992;46.

8. Khosh Khui M, Sink KC. Rooting-enhancement of Rosa hybrida for tissue culture propagation. Sci Hortic. 1982;17(4):371-376.

9. Lloyd D, Roberts AV, Short KC. The induction in vitro of adventitious shoots in Rosa. Euphytica. 1988;37(1):31-36.

10. Yao HJ, Luo XF, Tian YT. Development of explant browning researches. J Beijing Forest Univ. 1999;21:78-84.

11. Jin SX, Zhang XL, Liang SG, et al. Factors affecting transformation efficiency of embryogenic callus of upland cotton (Gossypium hirsutum) with Agrobacterium tumefaciens. Plant Cell Tiss Org Cult. 2005;81(2):237-329.

12. Alatzas A, Srebreva L, Foundouli A. Distribution of linker histone variants during plant cell differentiation in the developmental zones of the maize root, dedifferentiation in callus culture after auxin treatment. Biol res. 2008;41(2):205-215.

13. Murashige T, Skoog FA. A revised medium for rapid growth and bioassays with tobacco tissue culture. Physiol Plant. 1962;15(3):473497.

14. Kintzios S, Manos C, Makri O. Somatic embryogenesis from mature leaves of rose (Rosa sp.). Plant Cell Rep. 1999;18(6):467-472.

15. Malik KA, Saxena PK. Regeneration in Phaseolus vulgare L., high frequency induction of direct shoot formation in intact seedlings by
N6- benzylaminopurine and thidiazuron. Planta. 1992;186:384-389.

16. Saxena S, Brody AL, Schwartz JM, et al. Neuroimaging and frontalsubcortical circuitry in obsessive-compulsive disorder. Br J Psychiatry Suppl. 1998;35:26-37.

17. Fengyen L, Han L. Effect of exogenous hormones on micropropagation of In vitro virus free potato plantlets. Chines Potato J. 2002;16:214216.

18. Dodds J, Roberts L. Experiments in Plant Tissue Culture, $3^{\text {rd }}$ edition. New York: Cambridge University Press; 1995.

19. Chu CY, Knight SL, Smith MAL. Effect of liquid culture on the growth and development of miniature rose (Rosa chinensis Jacq. 'Minima'). Plant Cell Tiss Org Cult. 1993;32(3):329-334.

20. Tian N, Xu ZQ, He JG. Establishment of high frequency and direct regeneration system of Kiwi fruit (Actinidia deliciosa Qinmei). J Wuhan Botanical Research. 2007;25(1):79-83.

21. Nešković M, Vujičić R, Budimir S. Somatic embryogenesis and bud formation from immature embryos of buckwheat (Fagopyrum esculentum Moench.). Plant cell Rep. 1987;6(6):423-426.

22. He DG, Tanner G, Scott KJ. Somatic embryogenesis and morphogenesis in callus derived from the epiblast of immature embryos of wheat (Triticum aestivum). Plant Sci. 1986;45(2):119-124.

23. He DG, Yang YM, Scott KJ. Plant regeneration from protoplasts of wheat (Triticum aestivum cv. Hartog). Plant cell Rep. 1992;11(1):1619.

24. Tisserat B, Murashige T. Effects of ethephon, ethylene and 2, 4-dichlorophenoxyacetic acid on asexual embryogenesis In vitro. Plant Physiol. 1977;60(3):437-439.

25. Attree SM, Fowke LC. Embryogeny of gymnosperms: advances in synthetic seed technology of conifers. Plant Cell Tiss Org Cult. 1993;35(1):1-35.

26. Tokuji Y, Kuriyama K. Involvement of gibberellin and cytokinin in the formation of embryogenic cell clumps in carrot (Daucus carota). $J$ Plant Physiol. 2003;160(2):133-141.

27. Baker CM, Wetzstein HY. Influence of auxin type and concentration on peanut somatic embryogenesis. Plant Cell Tiss Org Cult. 1994;36(3):361-368.

28. Huetteman CA, Preece JE. Thidiazuron: a potent cytokinin for woody plant tissue culture. Plant Cell Tiss Org Cult. 1993;33(2):105-119.

29. Shan X, Li D, Qu R. Thidiazuron promotes in vitro regeneration of wheat and barley. In Vitro Cell Dev Biol Plant. 2000;36(3):207-210.

30. Sanikhani M, Frello S, Serek M. TDZ induces shoot regeneration in various Kalanchoe blossfeldiana Poelln. cultivars in the absence of auxin. Plant Cell Tiss Org Cult. 2006;85(1):75-82.

31. Wang J, Seliskar DM, Gallagher JL. Plant regeneration via somatic embryogenesis in the brackish wetland monocot Scirpus robustus. Aquat Bot. 2004;79(2):163-174.

32. Iantcheva A, Vlahova M, Bakalova E, et al. Regeneration of diploid annual medics via direct somatic embryogenesis promoted by thidiazuron and benzylaminopurine. Plant Cell Rep. 1999;18(11):904 910 .

33. Zahoor AS, Faheem A. Effect of thidiazuron(TDZ) on in vitro micropropagation of solanum tuberosum L.cvs. desiree and cardinal. Pak J Bot. 2009;41(4):1811-1815. 